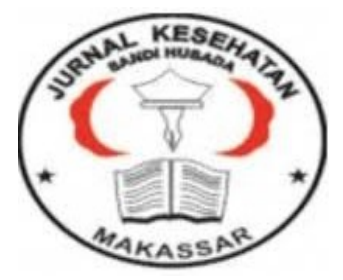

\author{
Jurnal Ilmiah Kesehatan Sandi Husada \\ hhttps://akper-sandikarsa.e-journal.id/JIKSH \\ Volume 12, Nomor 2, Desember 2020, pp 878-888 \\ p-ISSN: 2354-6093 dan e-ISSN: 2654-4563 \\ DOI: $10.35816 /$ jiskh.v10i2.429
}

\title{
Potensi Aktivitas Anti-Tuberkulosis Ekstrak Daun Pegagan (Centella Asiatica L. Urban) dalam Menghambat Pertumbuhan Mycobacterium Tuberculosa
}

Potential Anti-Tuberculosis Activity of Gotu Kola Leaf Extract (Centella Asiatica L. Urban) in Inhibiting the Growth of Mycobacterium Tuberculosa

\section{Tri Anti Permata Sari}

Program Studi Pendidikan Dokter Umum, Fakultas Kedokteran Universitas Lampung

\section{Artikel info}

\section{Artikel history:}

Received; Agustus 2020

Revised;September 2020

Accepted;September2020

\section{Abstract.}

Tuberculosis (TB) is still remain a disease that causes health issue in society. TB is a direct infectious lung disease caused by the TB germ (Mycobacterium tuberculosis) which is also known as acid fast bacteria (AFB). A survey conducted by the World Health Organization (WHO) around the world states that up to there are 9,000,000 incidents of cases and 1.5 million people died from $T B$, therefor TB is ranked as the 10th highest cause of death in the world. Indonesia itself ranks two of the most TB cases in the world. This paper aims to determine the potential and effectiveness of gotu kola leaf extract as an antituberculosis in inhibiting the growth of Mycobacterium. This research method is to review the articles with the keywords tuberculosis, gotu kola leaves, Mycobacterium tuberculosa, and anti-tuberculosis. The data show that giving gotu kola leaf extract can significantly reduce the growth of Mycobacterium tuberculosis, because gotu kola leaves contain bioactive compounds that have antimycobacterial activity. The consumption of gotu kola leaves together with TB medication is not dangerous and does not cause side effects, actually gotu kola leaves provide a hepatoprotective effect against the hepatotoxic effects caused by medication of TB. Gotu kola leaves also have the ability to increase the body's immune response because it is rich in antioxidants and can prevent lung tissue damage due to TB infection.
Abstrak.
Tuberkulosis (TB) masih menjadi salah satu penyakit yang menyebabkan masalah kesehatan di masyarakat Indonesia. TB adalah penyakit menular langsung paru yang disebabkan oleh kuman TB (Mycobacterium tuberculosis) yang juga dikenal sebagai bakteri tahan 
asam (BTA). Survei yang dilakukan oleh World Health Organization (WHO) menyatakan bahwa hingga kini di seluruh dunia terhitung 9.000.000 insiden kasus dan 1,5 juta orang meninggal karena $T B$, sehingga $T B$ mendapat peringkat 10 penyebab tertinggi kematian di dunia. Indonesia sendiri menduduki peringkat dua kasus TB terbanyak di dunia. Tulisan ini bertujuan untuk mengetahui potensi dan efektivitas ekstrak daun pegagan sebagai antituberkulosis dalam menghambat pertumbuhan Mycobacterium. Metode penelitian ini adalah dengan meninjau artikel review dengan kata kunci tuberkulosis, daun pegagan, Mycobacterium tuberculosa, dan antituberkulosis. Data menunjukkan bahwa pemberian ekstrak daun pegagan dapat menurunkan pertumbuhan Mycobacterium tuberculosis secara signifikan, karena daun pegagan memiliki kandungan senyawa bioaktif yang memiliki aktivitas anti-mikobakterial. Konsumsi daun pegagan bersamaan dengan obat anti tuberkulosis (OAT) tidak berbahaya dan tidak menimbulkan efek samping, justru daun pegagan memberikan efek hepatoprotektif terhadap dampak hepatotoksik yang ditimbulkan oleh OAT. Daun pegagan juga memiliki kemampuan untuk meningkatkan respon imunitas tubuh karena kaya akan kandungan antioksidan dan dapat mencegah kerusakan jaringan paru akibat infeksi TB.

Keywords:

Tuberkulosis; Gotu

kala Leaves;

Mycobacterium

tuberculosis.
Coresponden author:

Email: Trianti03@gmail.com

artikel dengan akses terbuka dibawah lisensi CC BY NC ND 4.0

\section{Pendahuluan}

Tuberkulosis (TB) masih menjadi salah satu penyakit yang menyebabkan masalah kesehatan di masyarakat Indonesia (Manalu, 2010). Tuberkulosis adalah penyakit menular langsung paru yang disebabkan oleh kuman TB (Mycobacterium tuberculosis) yang juga dikenal sebagai bakteri tahan asam (BTA). Mycobacterium selain Mycobacterium tuberculosis yang bisa menimbulkan gangguan pada saluran nafas dikenal sebagai MOTT (Mycobacterium Other Than Tuberculosis) yang terkadang bisa mengganggu penegakan diagnosis dan pengobatan TB paru. Gejala utama pasien TB paru yaitu batuk berdahak selama 2 minggu atau lebih. Batuk dapat diikuti dengan gejala tambahan yaitu dahak bercampur darah, batuk darah, sesak nafas, badan lemas, nafsu makan menurun, berat badan menurun, malaise, berkeringat malam hari tanpa kegiatan fisik, demam meriang lebih dari satu bulan. Pada pasien dengan HIV positif, batuk sering kali bukan merupakan gejala TB yang khas, sehingga gejala batuk tidak harus selalu selama 2 minggu atau lebih. Survei yang dilakukan oleh World Health Organization (WHO) menyatakan bahwa hingga kini di seluruh dunia terhitung 9.000.000 insiden kasus TB dan 1,5 juta orang meninggal karena TB (1,1 juta kematian diantara orang dengan HIV-negatif dan 360.000 kematian pada orang dengan HIV-positif). Secara global menurut survei WHO pada tahun 2013, angka kematian TB telah turun sebesar $45 \%$ dan tingkat prevalensi TB telah turun sebesar $41 \%$ dibandingkan pada tahun 1990, sedangkan menurut laporan Kementrian Kesehatan 
Republik Indonesia, jumlah kematian akibat tuberkulosis menurun $22 \%$ antara tahun 2000 dan 2015. Meskipun terdapat penurunan persentase mortalitas pada penderita TB, berdasarkan laporan WHO, TB masih menepati peringkat ke-10 penyebab kematian tertinggi di dunia pada tahun 2016. Oleh sebab itu, hingga kini TB masih menjadi prioritas utama di dunia dan menjadi salah satu agenda dalam Sustainability Development Goals (SDGs) (WHO, 2014; Kemenkes RI, 2018).

Hasil evaluasi yang dilakukan oleh Joint External Tuberculosis Monitoring (JEMM) menyatakan bahwa sebanyak 1.020 .000 penduduk di Indonesia pada tahun 2015 terdiagnosis penyakit TB dari total populasi Indonesia yang berjumlah sekitar 258.000.000 penduduk, dan kematian yang disebabkan TB mencapai 100.000 jiwa. Berdasarkan laporan WHO pada tahun 2016, kasus TB di Indonesia menduduki peringkat ke-2 dunia setelah India. Pemerintah melalui Permenkes Nomor 67 Tahun 2016 tentang Penanggulangan Tuberkulosis menetapkan target program Penanggulangan TB nasional yaitu eliminasi pada tahun 2035 dan Indonesia Bebas TB Tahun 2050. Eliminasi TB adalah tercapainya jumlah kasus TB 1 per 1.000 .000 penduduk. Target ini menjadi tantangan tersendiri bagi pemerintah dan tenaga medis, mengingat sementara ini pada tahun 2017 jumlah kasus TB sebesar 254 per 100.000 atau 25,40 per 1 juta penduduk (WHO, 2016; Kemenkes RI, 2018). Peningkatan kasus TB ini dapat disebabkan oleh berbagai faktor, diantaranya adalah kegagalan pengobatan, putus pengobatan, pengobatan tidak benar, penderita dengan keadaan imunosupresi dan absorbsi obat yang kurang adekuat. Salah satu dampak yang diakibatkan dari faktor-faktor tersebut yang ikut mempengaruhi peningkatan kasus TB di Indonesia adalah kejadian resistensi Mycobacterium terhadap pengobatan TB (Tirtana, 2011). Dewasa kini, telah banyak penelitian di bidang etnomedisin yang dilakukan terhadap tanaman herbal yang berpotensi dapat mengoptimalkan pengobatan TB. WHO sendiri pada tahun 2003 memberikan rekomendasi mengenai penggunaan obat tradisional termasuk herbal dalam pemeliharaan kesehatan masyarakat, pencegahan, dan pengobatan penyakit terutama penyakit kronis, degeneratif, dan kanker (WHO, 2003; WHO, 2016; Kemenkes RI, 2018).

Indonesia memiliki keanekaragaman hayati yang sangat banyak dan bervariasi, hingga kini terdapat sekitar 40.000 jenis tumbuhan yang tersebar. Kandungan kimia dan senyawa aktif dalam tumbuhan sangat banyak jenisnya, sehingga bila dieskplorasi dalam penelitian lebih lanjut dapat ditemukan manfaatnya didalam bidang pengobatan. Penelitian yang dilakukan oleh Fabricant dan Farnswoth dalam penelitian Irianti dkk, menyatakan bahwa 80\% dari 122 komponen senyawa pada 94 spesies tanaman dapat digunakan untuk tujuan etnomedisin. Sebanyak 39\% dari 520 obat yang disetujui antara tahun 1983-2004 berasal dari produk alam atau turunannya, dan sekitar $60-80 \%$ dari antibakteri dan antikanker berasal dari bahan alam. Daun pegagan merupakan salah satu tanaman yang bisa dijadikan esktrak untuk dikonsumsi untuk menghambat pertumbuhan Mycobacterium tuberculosis. Menurut penelitian terdahulu, daun pegagan sejak lama sudah digunakan dalam pengobatan Ayurveda dan pengobatan tradisional Cina. Daun pegagan terkenal akan kandungan triterpenoid yang dapat menghambat pertumbuhan mikobakterial dan kandungan antioksidan yang tinggi sehingga dapat juga mencegah kerusakan paru pada penderita TB. Oleh karena itu, penulis tertarik ingin mengetahui bagaimana potensi esktrak daun pegagan sebagai anti-tuberkulosis serta bagaimana dampaknya apabila dikonsumsi bersamaan dengan obat anti tuberkulosis (OAT). (Fansworth dan Fabricanth, 2001; Ghosh, Indra, Jagadeesan, 2017; Irianti dkk, 2018). 


\section{Metode}

Metode menggunakan studi pustaka dengan mengambil data dan referensi dari berbagai buku dan artikel ilmiah yang valid. Artikel tersebut dicari melalui data dari NCBI, PubMed, GoogleScholar, dan ResearchGate yang dibatasi dari 29 Agustus 2020 sampai dengan 4 September 2020 menggunakan kata kunci berupa: tuberkulosis, daun pegagan, Mycobacterium tuberculosa, dan anti-tuberkulosis. Desain penelitian pada artikel yang dipilih pada literature review ini adalah review sistematis, meta-analisis, dan penelitian eksperimental. Selanjutnya literatur melewati proses review dengan kriteria. Pencarian dengan menggunakan keyword diatas mendapatkan 45 literatur yang relevan. Sejumlah 17 artikel tidak memiliki kriteria inklusi, hanya 28 artikel yang kemudian disusun dalam literature review ini.

\section{Hasil dan Pembahasan}

\begin{tabular}{|c|c|c|c|c|c|}
\hline No & $\begin{array}{l}\text { Penulis dan } \\
\text { Tahun }\end{array}$ & Judul & $\begin{array}{c}\text { Desain } \\
\text { penelitian }\end{array}$ & Temuan & Perbandingan \\
\hline 1. & $\begin{array}{l}\text { Yusran, } \\
\text { Asriani, dan } \\
\text { Asri. (2016) }\end{array}$ & $\begin{array}{l}\text { Bioaktivitas } \\
\text { ekstrak methanol } \\
\text { daun pegagan } \\
\text { (Centella asiatica } \\
\text { l.) terhadap } \\
\text { pertumbuhan } \\
\text { bakteri } \\
\text { Myocobacterium } \\
\text { tuberculosis. }\end{array}$ & $\begin{array}{l}\text { Eksperimen } \\
\text { tal }\end{array}$ & $\begin{array}{l}\text { Ekstrak metanol } \\
\text { daun pegagan } \\
\text { merah dan daun } \\
\text { pegagan hijau } \\
\text { positif mampu } \\
\text { mengambat } \\
\text { pertumbuhan } \\
\text { bakteri } \\
\text { tuberculosis. }\end{array}$ & $\begin{array}{l}\text { Penelitian ini } \\
\text { menggunakan } \\
\text { esktrak } \\
\text { metanol daun } \\
\text { pegagan dalam } \\
\text { menguji } \\
\text { efektivitas. }\end{array}$ \\
\hline 2. & $\begin{array}{l}\text { Kumar, dkk. } \\
\text { (2014) }\end{array}$ & $\begin{array}{l}\text { Effect of Centella } \\
\text { asiatica against } \\
\text { anti-tuberculosis } \\
\text { drugs-induced } \\
\text { hepatotoxicity: } \\
\text { Involvement of } \\
\text { mitochondria and } \\
\text { oxidative stress }\end{array}$ & $\begin{array}{l}\text { Eksperimen } \\
\text { tal }\end{array}$ & $\begin{array}{l}\text { Ekstrak daun } \\
\text { pegagan } \\
\text { bermanfaat } \\
\text { dalam menekan } \\
\text { aktivitas } \\
\text { perumbuhan } \\
\text { Mycobacterium } \\
\text { tuberculosis dan } \\
\text { memiliki efek } \\
\text { hepatoprotektif } \\
\text { akibat obat anti } \\
\text { tuberkulosis } \\
\text { (isoniazid dan } \\
\text { rifampisin. }\end{array}$ & $\begin{array}{l}\text { Penelitian yang } \\
\text { dilakukan oleh } \\
\text { Kumar dengan } \\
\text { membandingka } \\
\mathrm{n} \text { pemberian } \\
\text { daun pegagan } \\
\text { peroral dengan } \\
\text { obat anti- } \\
\text { tuberkulosis } \\
\text { (OAT) yaitu } \\
\text { isoniazid dan } \\
\text { rifampisin, }\end{array}$ \\
\hline 3. & $\begin{array}{l}\text { Mickymaran } \\
\text { ' S., Rath } \\
\text { P.K., } \\
\text { Panneerselv } \\
\text { am A., } \\
\text { Dhanasekar } \\
\text { an D., } \\
\text { Thajuddin }\end{array}$ & $\begin{array}{l}\text { Anti- } \\
\text { mycobacterial } \\
\text { effect of leaf } \\
\text { extract of centella } \\
\text { asiatica } \\
\text { (Mackinlayaceae) }\end{array}$ & $\begin{array}{l}\text { Eksperimen } \\
\text { tal }\end{array}$ & $\begin{array}{l}\text { Kedua metode } \\
\text { kultur } \\
\text { konvensional } \\
\text { dengan } \\
\text { perlakuan berupa } \\
\text { pemberian } \\
\text { ekstrak daun } \\
\text { pegagan terbukti }\end{array}$ & $\begin{array}{l}\text { Penelitian ini } \\
\text { menggunakan } \\
\text { dua metode } \\
\text { media kultur } \\
\text { nyaitu } \\
\text { Lowenstein - } \\
\text { Jensen (L-J) dan } \\
\text { Versa- Trek }\end{array}$ \\
\hline
\end{tabular}




\begin{tabular}{|c|c|c|c|c|c|}
\hline & N. (2010) & & & $\begin{array}{l}\text { dapat } \\
\text { menghambat } \\
\text { pertumbuhan } M . \\
\text { tuberculosis } \\
\text { dengan sangat } \\
\text { efektif. }\end{array}$ & $\begin{array}{l}\text { rapid } \\
\text { culture system. }\end{array}$ \\
\hline 4. & $\begin{array}{l}\text { Mustika, } \\
\text { Anny, } \\
\text { Roostantia, } \\
2014\end{array}$ & $\begin{array}{l}\text { Penurunan } \\
\text { kerusakan } \\
\text { jaringan paru } \\
\text { terinfeksi } \\
\text { tuberkulosis oleh } \\
\text { ekstrak pegagan } \\
\text { melalui } \\
\text { peningkatan } \\
\text { ekspresi tissue } \\
\text { inhibitor of matrix } \\
\text { metalloproteinase } \\
-1\end{array}$ & $\begin{array}{l}\text { Eksperimen } \\
\text { tal }\end{array}$ & $\begin{array}{l}\text { Ekstrak etanol } C \text {. } \\
\text { asiatica } \\
\text { mempunyai } \\
\text { kemampuan } \\
\text { untuk } \\
\text { menurunkan } \\
\text { kerusakan } \\
\text { jaringan paru } \\
\text { tikus karena } \\
\text { tuberkulosis, } \\
\text { melalui } \\
\text { peningkatan } \\
\text { ekspresi tissue } \\
\text { inhibitor } \\
\text { matrix of } \\
\text { metalloproteinase } \\
\text {-1 (TIMP-1) }\end{array}$ & $\begin{array}{l}\text { Penelitian ini } \\
\text { dilakukan } \\
\text { untuk } \\
\text { mengetahui } \\
\text { pengaruh dan } \\
\text { mekanisme } \\
\text { ekstrak etanol } \\
\text { daun pegagan } \\
\text { dalam } \\
\text { memperbaiki } \\
\text { kerusakan } \\
\text { jaringan paru } \\
\text { tikus melalui } \\
\text { ekspresi } \\
\text { enzim TIMP-1. }\end{array}$ \\
\hline 6. & $\begin{array}{l}\text { Mustika, A, } \\
\text { (2015) }\end{array}$ & $\begin{array}{l}\text { Extract ethanol of } \\
\text { centella asiatica } \\
\text { reduce expression } \\
\text { of Mycobacterium } \\
\text { tuberculosis } \\
\text { antigen } \\
\text { alveolar } \\
\text { macrophage from } \\
\text { rats lung tissue } \\
\text { infected with } \\
\text { Mycobacterium } \\
\text { tuberculosis }\end{array}$ & $\begin{array}{l}\text { Eksperimen } \\
\text { tal }\end{array}$ & $\begin{array}{l}\text { Ekstrak etanol } \\
\text { daun pegagan } \\
\text { mengandung } \\
\text { bahan aktif yang } \\
\text { memiliki } \\
\text { kemampuan } \\
\text { untuk } \\
\text { menurunkan } \\
\text { ekspresi } \\
\text { antigen } \\
\text { tuberculosis pada } \\
\text { makrofag } \\
\text { alveolar }\end{array}$ & $\begin{array}{l}\text { Penelitian ini } \\
\text { lebih } \\
\text { menekankan } \\
\text { pada pengujian } \\
\text { ekstrak etanol } \\
\text { dalam } \\
\text { menurunkan } \\
\text { ekspresi } \\
\text { antigen } \\
\text { Mycobacterium } \\
\text { tuberculosis }\end{array}$ \\
\hline
\end{tabular}

Tuberkulosis (TB) adalah penyakit menular langsung paru yang disebabkan oleh kuman TB (Mycobacterium tuberculosis). Sebagian besar kuman ini menyerang paru, tetapi dapat juga mengenai organ tubuh lainnya. Bakteri ini berbentuk batang dan memiliki sifat tahan terhadap asam atau batang tahan asam (BTA). Batuk dapat diikuti dengan gejala tambahan yaitu dahak bercampur darah, batuk darah, sesak nafas, badan lemas, nafsu makan menurun, berat badan menurun, malaise, berkeringat malam hari tanpa kegiatan fisik, demam meriang lebih dari satu bulan. Pada pasien dengan HIV positif, batuk sering kali bukan merupakan gejala TB yang khas, sehingga gejala batuk tidak harus selalu selama 2 minggu atau lebih (Kemenkes RI, 2018). Penderita TB BTA (+) merupakan sumber penularan utama, terutama ketika penderita bersin atau batuk. (Kemenkes, 2018; Manalu, 2010). Klasifikasi TB dibagi menjadi dua yaitu TB paru dan TB ekstra paru, dimana TB paru adalah tuberkulosis yang menyerang jaringan paru, tidak termasuk pleura. Berdasarkan hasil pemeriksaan dahak (BTA) TB paru dibagi menjadi TB paru BTA $(+)$ dan TB paru BTA (-). TB paru BTA (+) harus memenuhi kriteria seperti sekurang- 
kurangnya 2 dari 3 spesimen dahak sewaktu-pagi-sewaktu (SPS) hasilnya BTA positif atau satu spesimen dahak SPS hasilnya BTA positif dan foto rontgen dada menunjukkan gambaran tuberkulosis aktif. Sedangkan TB paru BTA (-) harus memenuhi kriteria berupa pemeriksaan tiga spesimen dahak.(Singer, 2016; Depkes, 2014; Depkes, 2008)

Diagnosis TB paru ditegakkan melalui pemeriksaan gejala klinis, mikrobiologi, radiologi, dan patologi klinik. Gejala klinik TB dapat dibagi menjadi 2 golongan, yaitu gejala respiratorik dan gejala sistemik. Gejala respiratorik meliputi batuk lebih dari 3 minggu, batuk disertai darah, sesak napas, dan nyeri dada. Semua gejala ini sangat bervariasi, dimulai tidak ada gejala sampai gejala cukup berat tergantung luasnya perlukaan pada paru. Gejala sistemik meliputi demam dari rendah sampai tinggi, dan disertai dengan gejala sistemik yang lain seperti malaise, anoreksia, keringat malam, dan berat badan menurun yang merupakan ciri khas TB selain batuk berkepanjangan. Pemeriksaan dahak untuk penegakan diagnosis dilakukan dengan mengumpulkan 3 spesimen dahak yang dikumpulkan dalam dua hari kunjungan yang berurutan sewaktu-pagi-sewaktu (SPS). Pemeriksaan standar adalah foto toraks PA. Pemeriksaan lain atas indikasi ialah foto lateral, top lordotik, oblik, CT Scan. Pada kasus dimana pada pemeriksaan sputum SPS positif, foto toraks tidak diperlukan lagi (Kemenkes RI, 2018; Depkes, 2014; Depkes, 2008).

Pegagan merupakan salah satu jenis tanaman yang memiliki potensi untuk menjadi tanaman obat. Penelitian terdahulu melaporkan bahwa pegagan telah ditetapkan sebagai tanaman obat tradisional sejak tahun 1884. Keunggulan pegagan adalah selain memiliki kandungan antioksidan, anti-inflamasi, dan anti-mikrobakterial yang adekuat, pegagan mudah dicerna oleh tubuh dan toksisitasnya sangat rendah. Tanaman pegagan (Centella asiatica (L.) Urban.) dengan sinonim Hydrocotyle asiatica L. Pes, berasal dari daerah tropis di Asia. Berdasarkan klasifikasi taksonomi, pegagan termasuk ke dalam divisi Spermatophyta. subdivisi Angiospermae, kelas Dicotyledonae, ordo Umbillales, famili Umbilliferae (Apiaceae), genus Centella, spesies Centella asiatica (L.) Urban atau Hidrocotyle asiatica Linn. Pegagan secara umum tumbuh baik pada tanah yang agak lembap, dengan cukup sinar matahari. (Irham, Tamri, Marpaung, Marpongahtun, 2019; Sutardi, 2016; Arumugam, Ayyanar, Pillai dan Sekar, 2011).

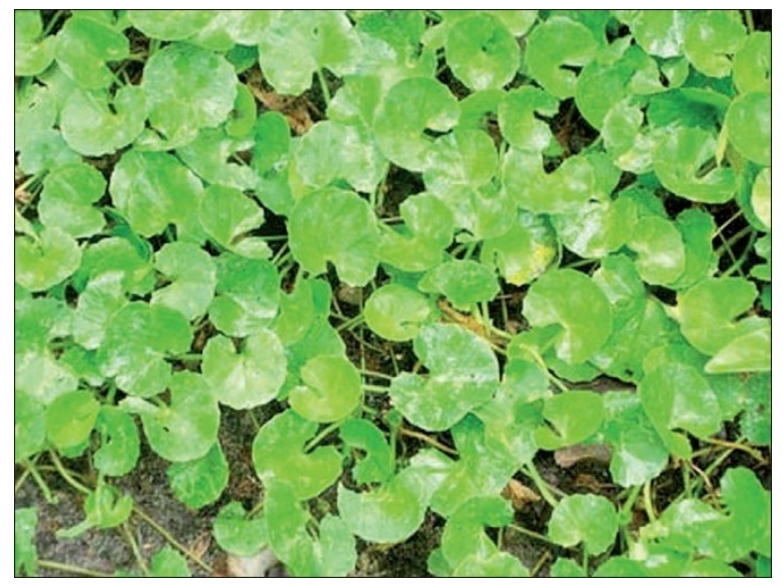

Gambar 1. Daun Pegagan (Gohil, Patel, Gajjar 2010)

Beberapa komponen bioaktif dalam tanaman pegagan adalah asiatikosida, tankunisida, isotankunisida, madekasosida, brahmosida, brahminosida, asam brahmik, asam madasiatik, meso-inositol, sentelosida, karotenoid, hidrokotilin, vellarin, tanin serta garam mineral seperti kalium, natrium, magnesium, kalsium, dan, fosfor, minyak atsiri, dan 
pektin. Asiatikosida, asam asiatik, madekasida, dan madekasosida termasuk golongan triterpenoid, sementara sitosterol dan stigmasterol termasuk golongan steroid serta vallerin brahmosida golongan saponin. Asiatikosida merupakan glikosida triterpen, derivat alfaamarin dengan molekul gula yang terdiri atas dua glukosa dan satu rhamnosa. Aglikon triterpen pada pegagan disebut asiatikosida yang mempunyai gugus alkohol primer, glikol, dan satu karboksilat teresterifikasi dengan gugus gula. Secara garis besar dari semua kandungan bioaktif yang terdapat pada pegagan, triterpenoid merupakan senyawa yang paling penting dalam tanaman pegagan (Gohil, Patel, Gajjar, 2010; Hashim, 2011; Roy,Barman, Shaik, 2013; Sultan, Mahmood, Azhar, Ahmed, Mahmood, 2014; Sutardi, 2016; Prakash, Jaiswal, dan Srivastava, 2017).

\section{Peran Ekstrak Daun Pegagan sebagai Inhibitor Pertumbuhan Mycobacterium Tuberculosa pada Penyakit Tuberkulosis}

Menurut penelitian Kumar, dkk daun pegagan memiliki kandungan senyawa bioaktif golongan triterpen yaitu asam asiatikosida, asam madekasat, dan asam madekosida yang efektif secara langsung dalam memghambat pertumbuhan Mycobacterium tuberculosis. Hasil penelitian ini diperkuat oleh penelitian yang dilakukan oleh Yusran, Asriani, dan Asri, dimana mereka juga menyatakan bahwa daun pegagan memiliki kandungan senyawa triterpen, yang merupakan metabolit sekunder dengan potensi untuk menghambat pertumbuhan Mycobacterium tuberculosis dengan menghambat sintesis protein bakteri tersebut. Proses sintesis protein pada bakteri ini terdiri dari dua tahap yaitu transkripsi dan translasi. Tahap transkripsi adalah proses penguraian molekul asam deoksiribonukleat (DNA) menjadi asam ribonukleat (RNA) yang dikatalisasi dengan enzim RNA polimerase. Mekanisme inhibisi pertumbuhan bakteri terjadi pada tahap ini, dimana enzim RNA polimerase cenderung akan melekat pada senyawa asam asiatikosida, sehingga menyebabkan terhambatnya fungsi pembentukan RNA dan proses sintesis protein, yang mengakibatkan penurunan pertumbuhan bakteri. Mereka menguji esktrak metanol daun pegagan merah dan hijau melalui uji aktivitas antibakteri dengan metode microscopic observation drug susceptibility (MODS) menggunakan plat petri 24 hole. Hasil penelitian ini menyatakan ekstrak metanol daun pegagan merah dan daun pegagan hijau mampu mengambat pertumbuhan Mycobacterium tuberculosis secara optimal pada konsentrasi $80 \%$ dan 100\% yang ditandai dengan tidak adanya pertumbuhan jumlah koloni bakteri. Mereka menyimpulkan bahwa konsumsi daun pegagan secara langsung terbukti aman dan efektif dalam membantu menurunkan pertumbuhan Mycobacterium sehingga dapat digunakan dalam pengobatan tuberkulosis (Yusran, Asriani, dan Asri, 2016; Kumar, dkk, 2014).

Selanjutnya Mickymaray, dkk melakukan uji suseptibilitas Mycobacterium tuberculosis dengan ekstrak etanol daun pegagan pada media kultur Versa-Trek dan evaluasi aktivitas anti-mikobakterial dalam ekstrak etanol di medium Lowenstein-Jensen (LJ). Melalui penelitian tersebut, didapatkan hasil bahwa ekstrak etanol daun pegagan terbukti efektif dalam menghambat pertumbuhan mikobakterial ini dan juga aman untuk dikonsumsi berdampingan dengan obat anti tuberkulosis (OAT). Ekstrak etanol daun pegagan ini selanjutnya dianalisis oleh GC-MS analysis, dan didapatkakn bahwa senyawa bioaktif utama yang terdapat dalam ekstrak adalah octadectrienoic acid dan $n$-hexadecanoic acid. Penemuan ini diperkuat dengan penelitian yang dilakukan oleh Ojo, dkk yang menyatakan bahwa kedua senyawa bioaktif ini memiliki aktivitas anti-tuberkulosis yang adekuat untuk menghambat pertumbuhan mikobakterium penyebab tuberkulosis (Mickymaray, Rathm Paneerselvam, Thajuddin, 2010; Ojo, dkk, 2018). 
Tabel 1. Evaluasi aktivitas anti mikobakterial dalam ekstrak etanol pegagan dalam media L

\begin{tabular}{|c|c|c|}
\hline $\begin{array}{c}\text { Konsentrasi ekstrak etanol } \\
\text { daun pegagan (mg) }\end{array}$ & $\begin{array}{c}\text { Pertumbuhan bakteri (dalam } \\
\text { hari) }\end{array}$ & Status \\
\hline 10 & $\begin{array}{l}\text { Terdapat pertumbuhan bakteri } \\
\text { dalam } 4 \text { minggu (jumlah koloni } \\
\text { 5) }\end{array}$ & Suseptibel parsial \\
\hline 50 & $\begin{array}{l}\text { Terdapat pertumbuhan bakteri } \\
\text { dalam } 4 \text { minggu (jumlah koloni } \\
\text { 4) }\end{array}$ & Suseptibel parsial \\
\hline 100 & $\begin{array}{l}\text { Terdapat pertumbuhan bakteri } \\
\text { dalam } 4 \text { minggu (jumlah koloni } \\
\text { 3) }\end{array}$ & Suseptibel parsial \\
\hline 200 & $\begin{array}{l}\text { Tidak ada pertumbuhan koloni } \\
\text { dalam masa inkubasi selama } 4 \\
\text { minggu }\end{array}$ & Suseptibel \\
\hline 300 & $\begin{array}{l}\text { Tidak ada pertumbuhan koloni } \\
\text { dalam masa inkubasi selama } 4 \\
\text { minggu }\end{array}$ & Suseptibel \\
\hline 400 & $\begin{array}{l}\text { Tidak ada pertumbuhan koloni } \\
\text { dalam masa inkubasi selama } 4 \\
\text { minggu }\end{array}$ & Suseptibel \\
\hline 500 & $\begin{array}{l}\text { Tidak ada pertumbuhan koloni } \\
\text { dalam masa inkubasi selama } 4 \\
\text { minggu }\end{array}$ & Suseptibel \\
\hline Kontrol & $\begin{array}{l}\text { Terdapat pertumbuhan koloni } \\
\text { dalam masa inkubasi selama } 4 \\
\text { minggu; jumlah koloni }>20 \\
\text { minggu. }\end{array}$ & - \\
\hline \multicolumn{3}{|c|}{$\begin{array}{l}\text { Tabel 2. Uji Suseptibilitas Mikobakterial dengan Ekstrak Etanol Pegagan di dalam } \\
\text { Versa-Trek Rapid Culture System }\end{array}$} \\
\hline $\begin{array}{c}\text { Konsentrasi ekstrak etanol } \\
\text { daun pegagan (mg) }\end{array}$ & $\begin{array}{c}\text { Pertumbuhan bakteri (dalam } \\
\text { hari) }\end{array}$ & Status \\
\hline 10 & $\begin{array}{l}\text { Terdapat pertumbuhan bakteri } \\
\text { dalam } 10 \text { hari }\end{array}$ & Resisten \\
\hline 50 & $\begin{array}{l}\text { Terdapat pertumbuhan bakteri } \\
\text { dalam } 10 \text { hari }\end{array}$ & Resisten \\
\hline 100 & $\begin{array}{l}\text { Terdapat pertumbuhan bakteri } \\
\text { dalam } 11 \text { hari }\end{array}$ & Resisten \\
\hline 200 & $\begin{array}{l}\text { Terdapat pertumbuhan bakteri } \\
\text { dalam } 12 \text { hari }\end{array}$ & Suseptibel \\
\hline 300 & $\begin{array}{l}\text { Terdapat pertumbuhan bakteri } \\
\text { dalam } 12 \text { hari }\end{array}$ & Suseptibel \\
\hline 400 & $\begin{array}{l}\text { Tidak ada pertumbuhan bakteri } \\
<16 \text { hari }\end{array}$ & Suseptibel \\
\hline 500 & $\begin{array}{l}\text { Tidak ada pertumbuhan bakteri } \\
<16 \text { hari }\end{array}$ & Suseptibel \\
\hline Kontrol & $\begin{array}{l}\text { Terdapat pertumbuhan bakteri } \\
\text { dalam } 8 \text { hari }\end{array}$ & - \\
\hline
\end{tabular}


Konsentrasi terendah ekstrak etanol daun pegagan yang digunakan menghambat pertumbuhan dari Mycobacterium tuberculosis adalah 200mg hingga 12 hari (masa inkubasi) yang dibandingkan dengan kontrol.

Keterangan:

Kontrol : Mycobacterium tuberculosis tanpa diberi perlakuan.

Suseptibel : Tidak ada pertumbuhan Mycobacterium positif minimal lebih dari 3 hari setelah kontrol positif.

Resisten : Pertumbuhan Mycobacterium sebelum atau setelah kontrol positif, namun $<3$ hari setelah kontrol positif.

Penelitian lain yang memperkuat hasil penelitian diatas dilakukan oleh Rimporok, Budiarso, dan Fatmawati, dimana hasil penelitian mereka dengan metode dilusi cair dan padat, menyatakan bahwa ekstrak etanol daun pegagan menunjukkan konsentransi hambat minimum (KHM) pada konsentrasi 25\%, 75\%, dan 100\%. Sedangkan untuk konsentrasi bunuh minimum (KBM) masih ditemukan mikobakterium pada konsentrasi 25\%, 75\%, dan 100\%. Penelitian tersebut menegaskan bahwa ekstrak etanol daun pegagan dapat menghambat tetapi tidak dapat membunuh Mycobacterium tuberculosis. Hasil positif daya hambat ekstrak etanol daun pegagan terhadap mikobakterium disebabkan karena adanya kandungan saponin dan steroid. Saponin berperan sebagai anti-mikobakterial dengan menyebabkan kebocoran protein dan enzim di dalam bakteri, sedangkan mekanisme steroid sebagai anti-mikobakterial adalah dengan berinteraksi dengan membran sel yang menyebabkan membran rapuh hingga akhirnya lisis (Rimporok, Budiarso, dan Fatmawati, 2020). Kemudian penelitian lain yang dilakukan oleh Kumar dkk, juga menyatakan bahwa konsumsi daun pegagan bersamaan dengan OAT tidak berbahaya dan menimbulkan efek samping. Daun pegagan justru memberikan efek hepatoprotektif terhadap dampak hepatotoksik yang ditimbulkan oleh OAT. Seperti yang telah diketahui, isoniazid dan rifampisin dimetabolisme di hepar melalui proses asetilasi dan hidrolisis dan menghasilkan metabolit yang bersifat toksin bagi hepar. Selain itu kedua OAT ini juga menginduksi stress oksidatif yang mengakibatkan kerusakan hepatosit, dan penelitian ini menyatakan bahwa ekstrak daun pegagan mampu menurunkan kadar lipid peroksidase dan reactive oxygen species (ROS) sehingga dapat mencegah stress oksidatif selular. Daun pegagan juga memiliki kandungan antioksidan yang cukup tinggi sehingga dapat mencegah terjadinya disfungsi mitokondria hepatosit dan mencegah kerusak oksidatif hepar (Kumar, dkk, 2014).

Penelitian lain yang dilakukan pada 28 tikus jantan yang diinfeksi dengan Mycobacterium tuberculosis strain $\mathrm{H} 37 \mathrm{Rv}$ menunjukkan bahwa pemberian ekstrak etanol daun pegagan $750 \mathrm{mg} / \mathrm{kgBW}$ and $1500 \mathrm{mg} / \mathrm{kgBW}$, menurunkan ekspresi antigen mikobakterial di makrofag alveolar secara signifikan. Hal ini disebabkan karena daun pegagan memiliki senyawa aktif yang mampu menurunkan ekspresi antigen mikrobial tersebut. Daun pegagan juga memiliki kemampuan untuk meningkatkan respon imunitas tubuh dan menghambat pertumbuhan mikrobakterial ini secara in vivo. Selain itu pemberian ekstrak etanol daun pegagan juga dapat mencegah kerusakan jaringan paru yang diinduksi oleh mikrobakterial penyebab tuberkulosis. Hal ini disebabkan karena mikrobakterial ini akan meningkatkan ekspresi metalloproteinase-1 (MMP-1). Enzim MMP-1 ini dapat menyebabkan degradasi terhadap kolagen tipe I yang menyebabkan kerusakan jaringan paru. Hasil penelitian tersebut mengungkapkan bahwa kandungan senyawa aktif dalam ekstrak etanol daun pegagan mampu menurunkan eskpresi MMP-1 sehingga dapat mencegah kerusakan kolagen alveolar paru penderita TB. Selain itu, mekanisme ekstrak etanol daun pegagan dalam meningkatkan resolusi jaringan paru juga bisa disebabkan karena ekstrak etanol daun pegagan mengandung bahan aktif asiaticosida yang diduga mempunyai kemampuan untuk meningkatkan sintesis kolagen. Oleh karena itu, 
kemungkinan mekanisme kerja ekstrak etanol daun pegagan dalam memperbaiki kerusakan jaringan paru melalui dua hal yaitu, melalui hambatan ekspresi enzim MMP-1 dan peningkatan sintesis kolagen (Mustika, Anny, Roostantia, 2014).

\section{Simpulan Dan Saran}

Tuberkulosis (TB) masih menjadi salah satu penyakit yang menyebabkan masalah kesehatan di masyarakat Indonesia. TB adalah penyakit menular langsung paru yang disebabkan oleh kuman TB (Mycobacterium tuberculosis) yang juga dikenal sebagai bakteri tahan asam (BTA). Kasus TB di dunia dan di Indonesia masih sangat tinggi, sehingga diperlukan pengobatan herbal yang dapat dapat diberikan bersamaan dengan obat anti tuberkulosis (OAT) yang tidak menimbulkan reaksi obat dan efek samping, serta dapat menghambat pertumbuhan Mycobacterium tuberculosis. Pemberian ekstrak daun pegagan dapat menurunkan pertumbuhan mikobakterial secara signifikan, karena daun pegagan memiliki kandungan senyawa bioaktif yang memiliki aktivitas anti-mikobakterial. Konsumsi daun pegagan bersamaan dengan OAT tidak berbahaya dan menimbulkan efek samping, justru daun pegagan memberikan efek hepatoprotektif terhadap dampak hepatotoksik yang ditimbulkan oleh OAT. Daun pegagan juga memiliki kemampuan untuk meningkatkan respon imunitas tubuh karena kaya akan kandungan antioksidan dan dapat mencegah kerusakan jaringan paru pada penderita TB.

\section{Daftar Rujukan}

Arumugam, T., M. Ayyanar, Y.J.K. Pillai and T. Sekar. (2011). Phytochemical screening and antibacterial activity of leaf and callus extracts of Centella Asiatica. Bangladesh J. Pharmacol, 6, 55-60.

Dahiya, P., Purkayastha, S. (2012). Phytochemical screening and antimicrobial activity of some medicinal plants against multi-drug resistant bacteria from clinical isolates. Indian Journal of Pharmaceutical Sciences, 74(5), 443.

Departemen Kesehatan RI. (2008). Pedoman Nasional Penanggulangan Tuberkulosis, edisi 2, Jakarta: Dirjen P2M\&PL.

Departemen Kesehatan RI. (2014). Info DATIN: Tuberkulosis, Temukan, Obati sampai Sembuh. Jakarta: Kementerian Kesehatan RI.

Fansworth, N.R., \& Fabricant, D.S. (2001). The value of plants used in traditional medicine for drug discovery. Environ Health Perspect, 109, 69-75.

Ghosh, K., Indra, N., \& Jagadeesan, G. (2017). The ameliorating effect of Centella asiatica ethanolic extract on albino rats treated with isoniazid. Journal of Basic and Clinical Physiology and Pharmacology, 28(1).

Gohil, K. J., Patel, J. A., \& Gajjar, A. K. (2010). Pharmacological Review on Centella asiatica: A Potential Herbal Cure-all. Indian journal of pharmaceutical sciences, 72(5), 546556.

Hashim, P. (2011). Centella asiatica in food and beverage applications and its potential antioxidant and neuroprotective effect. Int Food Res J, 18, 1215-22

Irham, W. H., Tamrin, Marpaung, L., \& Marpongahtun. (2019). Bioactive Compounds In Pegagan Leaf (Centella asiatica L. Urban) for Wound Healing. Journal of Physics: Conference Series, 1232

Irianti, dkk. (2018). Aktivitas Anti-Tuberkulosis Ekstrak Etil Asetat Daun Kenikir (Cosmos caudatus H.B.K) dan Daun Sendok (Plantago major L.) Secara In Vitro. Trad. Med. J. 23(1), 1-8. 
Kemenkes RI. (2018). InfoDATIN Tuberkulosis. (2018). Jakarta: Pusat Data dan Informasi Kementrian Kesehatan RI.

Kumar, V., Ankur S., Lalit M., K. Nagarajan, Shadab A.S. (2014). Effect of Centella asiatica against anti-tuberculosis drugs-induced hepatotoxicity: Involvement of mitochondria and oxidative stress. The Journal of Phytopharmacology. 3(5), 310-5

Manalu, H.S.P. (2010). Faktor-faktor yang mempengaruhi kejadian TB paru dan upaya penanggulangannya. Jurnal Ekologi Kesehatan. 9(4), 1340-1346.

Mickymaran, S., Rath P.K., Panneerselvam A., Dhanasekaran D., Thajuddin N. (2010). Antimycobacterial effect of leaf extract of centella asiatica (Mackinlayaceae). Research J. Pharm. and Tech. 3(3)

Mustika, A., Anny S.R., Roostantia I. (2014). Penurunan kerusakan jaringan paru terinfeksi tuberkulosis oleh ekstrak pegagan melalui peningkatan ekspresi tissue inhibitor of matrix metalloproteinase-1. Jurnal Veteriner. 15(4), 530-40.

Mustika, Arifa. (2015). Extract ethanol of centella asiatica reduce expression of Mycobacterium tuberculosis antigen on alveolar macrophage from rats lung tissue infected with Mycobacterium tuberculosis. In: The 9th Asia Pacific IAP Congress, 47 Juni 2015, Brisbane, Queensland, Australia.

Ojo, dkk. (2018). Anti-tubercular activities and molecular characterization of salivary extract of leech against mycobacterium tuberculosis. Journal of Tuberculosis Research, 06(01), 1-9.

Prakash, V., Jaiswal, N., \& Srivastava, M. (2017). A Review On Medicinal Properties Of Centella Asiatica. Asian Journal of Pharmaceutical and Clinical Research, 10(10), 69.

Rimporok, A., Fona B., Fatimawati. 2020. Uji anti bakteri ekstrak daun tanaman kaki kuda (centella asiatica L. Urban) sebagai tumbuhan obat anti tuberkulosis. Jurnal Biomedik. 12(1, 31-7.

Roy DC, Barman SK, Shaik MM. (2013). Current updates on Centella asiatica: Phytochemistry, pharmacology and traditional uses. Med Plant Res. 3(4), 70-7

Shukla SD, Bhatnagar M, Khurana S. (2012). Critical Evaluation of Ayurvedic Plants for Stimulating Intrinsic Antioxidant Response. Front Neurosci. 6, 112.

Singer-Leshinsky, S. (2016). Pulmonary tuberculosis. Journal of the American Academy of Physician Assistants, 29(2), 20-25.

Sultan RA, Mahmood SB, Azhar I, Ahmed SW, Mahmood ZA. Biological activities assessment of Centella asiatica (Linn.). J Herbs Spices Med Plants 2014;20(3):31927

Sutardi, S. (2017). Kandungan Bahan Aktif Tanaman Pegagan dan Khasiatnya untuk Meningkatkan Sistem Imun Tubuh. Jurnal Penelitian Dan Pengembangan Pertanian, 35(3), 121.

Tirtana, B.T. (2011). Faktor-faktor yang mempengaruhi keberhasilan pengobatan pada pasien tuberkulosis paru dengan resistensi obat tuberkulosis di wilayah jawa tengah. Skripsi. Fakultas Kedokteran Universitas Diponegoro, Semarang

World Health Organization (WHO), 2003, Adherence to long-term therapies: evidence for action, World Health Organization, Geneva.

World Health Organization (WHO), 2016, Global Tuberculosis Report 2016, World Health Organization, Geneva.

Yusran, Asriani I., H. Asri S. (2016). Biokativitas ekstrak methanol daun pegagan (centella asiatica l.) terhadap pertumbuhan bakteri myocobacterium tuberculosis. Ak-kimia. $4(1)$, 